\title{
Przyczynki
}

\section{Pożegnanie z Bronisławą Waligórską. Praktyki biograficzne}

Monika Rudaś-Grodzka

TEKSTY DRUGIE 2019, NR 1, S. 287-302

DOI: 10.18318/td.2019.1.20 | ORCID: 0000-0002-2939-9583

$\boldsymbol{L}_{\text {grafyz } \text { cytadeli. ale edycją listów zapomnianej, niemal niezna- }}$ nej działaczki partii Proletariat'․ Książka, która zaraz po wydaniu cudem znalazła się na witrynie akademickiej księgarni, sprawiała wrażenie przedmiotu przez przypadek tam porzuconego. Wciśnięta między żeberka stojaka, wyglądała, jakby ledwo stała na jednej nodze i zaraz miała spaść w otchłań kurzu i zapomnienia. Nie wydało mi się to dziwne. Był to ostatni, uzupełniający akord pośmiertnego życia Waligórskiej i mojej pracy nad jej listami.

Pełne trudów życie niedoszłej terrorystki obfitowało w porażki i katastrofy. Historia nie polubiła Waligórskiej, nie przewidziała dla niej szczególnego miejsca w ludzkiej pamięci, a nieliczne ślady zostały zamknięte w jednej szaroburej teczce ${ }^{2}$. Nie powiodło się jej ani w życiu prywatnym, ani zawodowym, lecz takich przykładów znamy

1 B. Waligórska Listy z cytadeli. 1886, Wydawnictwo IBL PAN, Warszawa 2018.

2 Autografy listów znajdują się w Muzeum Adama Mickiewicza w Paryżu, sygn. 1109.
Monika Rudaś-

-Grodzka - dr hab., kierowniczka Zespołu Archiwum Kobiet, pracowniczka IBL PAN, przewodnicząca Komitetu Redakcyjnego serii monograficznej „Lupa Obscura"i serii edycji źródłowych "Archiwum Kobiet". Ostatnio wydała Listy z cytadeli. 1886 Bronisławy Waligórskiej (2018). 
wiele. Nieoczekiwanie stanęła na mojej drodze i teraz powinnam postawić trzy kropki..., gdyż otwierają się tu przestrzeń i czas, jaki z nią przeżyłam. Była to przygoda intelektualna i duchowa. I jeśli nie mogę siebie nazwać jej biografką, to jednak w mojej pracy używałam techniki biograficznej.

Tego rodzaju praktyka zajmuje centralne miejsce w naukach historycznych. Ale paradoksalnie przez lata biografia nie była szanowana ani ceniona przez badaczy, chociaż ich prace bardzo często mają charakter stricte biograficzny. Odżegnywano się od biografii z powodu jej skłonności do metaforyzowania i łatwości deprecjonowania czy bagatelizowania źródeł. Zarzucano jej ponadto płytkość, popularyzatorskość, nadmierne liczenie się z oczekiwaniami czytelników/czytelniczek, a nie z przedmiotem badań etc. Rzadko przyznawano się, że jest to sztuka trudna, wymagająca co najmniej podstawowych zdolności artystycznych. Z drugiej zaś strony musimy przyznać, że talent pisarski i umiejętność wymyślania historii nie wystarczają. U podłoża badań historycznych i biograficznych znajdują się ludzkie pragnienie i dążenie do prawdy. W czasach fake news, kiedy obserwujemy wielki powrót prawdy z banicji, zaczynamy doceniać, jak ważna jest to kategoria polityczna, epistemologiczna, psychologiczna i moralna ${ }^{3}$. Mamy też świadomość, że chęć odnalezienia prawdy na podstawie faktów często pozostaje tylko idealistycznym założeniem. Chociażby z tego względu, że żyjące czy zmarłe osoby miały zbyt wiele do ukrycia albo z jakichś innych powodów zakładały maskę bądź pilnowały swojej prywatności. Piszący biografię rzadko wiedzą, gdzie szukać tętna ich bohaterów, trudno jest bowiem dotrzeć do życia wewnętrznego. Nawet jeśli mamy ślady w postaci osobistych zapisów snów, marzeń i pragnień, nigdy nie zdobędziemy pewności, czy rzeczywiście tworzą one główną materię badań biograficznych.

A jednocześnie nie możemy zapominać, że biografia jest literaturą, na dodatek bardzo chętnie pisaną i czytaną - tak było sto lat temu i tak dzieje się obecnie. Już Virginia Woolf z zadowoleniem odnotowywała ogromne zainteresowanie biografią i wieszczyła jej wielką karierę. się od jej czasów. Na pytanie, dlaczego co najmniej od XVII wieku ludzie wybierają tak chętnie ten typ literatury, Anna Nasiłowska, autorka książek o Marii Pawlikowskiej-Jasnorzewskiej, Yoshiho Umedzie, Jean-Paul Sartrze i Simone de Beauvoir, twierdzi, że czytelników/czytelniczki i biografów/

3 Pomijam tu efekty postmodernistycznych eksperymentów odrzucających istnienie prawdy czy postlacanowskich dowodów, że równie silne jest w nas pragnienie prawdy, jak bycie oszukiwanym.

4 V. Woolf Sztuka biografii, w: Eseje wybrane, przeł. M. Heydel, Karakter, Kraków 2015, s. 321. 
biografki pociąga ukryte życie ${ }^{5}$. Zgadza się ona również z tezą, że biografia ma charakter substytutywny, pozwala na przeżywanie cudzego istnienia w zastępstwie swojego, a także na uwolnienie fantazji, odkrywanie nieuświadomionych marzeń - dzięki poznawaniu innych losów, które stają się lustrem odbijającym to, co niewyrażone.

Mimo wielu ograniczeń nic nie jest w stanie zatrzymać triumfalnego pochodu biografii: ani procesy sądowe, ani rodzina, ani interesy państwowe $e^{6}$. Sukces zapewniają jej narracyjność i samo życie w swoim bogactwie nieskąpiące różnorodnych wątków, których nie wymyśli najzdolniejszy scenarzysta nawet po zażyciu LSD. Przede wszystkim od biografii oczekuje się sugestywności i dramatyczności, powinna być dobrze napisana, a biograf musi w nią tchnąć ożywczego ducha, bo czytelnik szuka rozkoszy, pozwalającej mu zanurzyć się w cudzych sukcesach i klęskach. Skala pragnień jest ogromna. Jarosze szukają odpowiedzi na własne pytania, mięsożercy zasadzają się na krwawe łupy, wśród biografów są nie tylko wiotkie mimozy czy subtelne artystki, ale także kanibale i hieny.

A przecież historyk czy historyczka mają do czynienia z duchami i muszą nauczyć się z nimi obchodzić.

\section{Life writing i duch}

Dlaczego uparcie wracam myślami do Waligórskiej? Bo widzę, że odchodzi ona z mojego życia, jest więc inaczej, niż chciał Jacques Derrida, głęboko wierzący i dowodzący, że obraz osoby zmarłej staje się częścią naszego „ja”.

Według Derridy człowiek po śmierci istnieje w sposób szczególny, staje się obrazem samego siebie, nie należy więc do umarłego i nie należy też do nas, choć zamieszkuje w naszej pamięci. Reprezentacja zmarłego, która wprowadza się do naszej podmiotowości, „prowadzi własny żywot”. Rodzi się pytanie: czy zmarły we mnie to coś więcej czy mniej niż obraz? Pojawia się on często mimowolnie albo świadomie przywołujemy go we wspomnieniach. Polemizując z Zygmuntem Freudem, Derrida uważa, że niemożliwe jest rozstanie ze zmarłym ${ }^{8}$.

5 A. Nasiłowska rozmowa prywatna, Żoliborz, 14 sierpnia 2018.

6 Zob. J. Malcolm Milczq̨ca kobieta. Sylvia i Ted Hughes, przeł. M. Michałowska, Zysk i S-ka, Poznań 1998.

7 J. Derrida The Work of Mourning, The University of Chicago Press, Chicago 2001.

8 P. Sadzik Żałoba (część 1) - (według) Derridy, http://malakulturawspolczesna.org/2012/11/21/ piotr-sadzik-zaloba-cz-1-wedlug-derridy/ (5.09.2018). 
Podążając za jego myślą, mogę powiedzieć, że jeżeli Waligórska jest we mnie, to oznacza, że naruszyła granice mojej podmiotowości, stała się częścią mnie i przypomina jątrzącą się ranę. Zatem nie mogę jej wyrzucić poza siebie, wrosła bowiem we mnie, a próba wyswobodzenia się mogłaby okazać się bolesną operacją. Nie sposób jej więc oswoić ani usunąć. Etycznym obowiązkiem jest niepozbywanie się tego stanu nawiedzenia, niepewności, dziwności i niepokoju. To znamię. Należy je pielęgnować poprzez mówienie/ niemówienie, pisanie/niepisanie, dotykanie/niedotykanie.

Jednak moje doświadczenie jest odmienne, mam wrażenie, że niedoszła terrorystka wkroczyła do mojego życia i teraz odchodzi na zawsze, i rację przyznaję Walterowi Benjaminowi, który pisał, że „prawdziwy obraz przeszłości umyka obok. Przeszłość można uchwycić tylko jako obraz, który w chwili swojej rozpoznawalności właśnie rozbłyska na wieczne pożegnanie"9. To zdanie towarzyszyło mojemu namysłowi nad spotkaniem z przeszłością, po której został ślad w postaci książki, obecnie prowadzącej własne niezależne, krótkie życie, skazane również na zapomnienie. Nasza pamięć jest plastyczna, podatna na zmiany, ale niczego nie usuwa, więc z pewnością Waligórska będzie wiodła swoje senne życie w głębszych pokładach mojej nieświadomości, ale nie tak jak dotychczas, dlatego należy jej się pożegnanie. Zrozumiałam, że nie wolno podporządkować zmarłych naszym celom ani nie można pozwolić im się uwieść, trzeba zgodzić się, żeby widma wchodziły w nas i wychodziły oraz dać im miejsce w naszej pamięci za pomocą naszego pisma, które wywołuje ich głosy. Pisanie, będące naszym łącznikiem ze zmarłymi, musi pozostać tylko cytatem ${ }^{\mathbf{1 0}}$. Podtrzymany zostanie wtedy konieczny dystans między nami a nimi.

Moja relacja z Waligórską była trudna: przyczyniły się do tego nie tylko nasze charaktery, ale również czynniki zewnętrzne, nieliczne źródła, zła pogoda, nieżyczliwi i niekompetentni ludzie. Mimo moich starań od początku nic nie wychodziło tak, jak planowałam, co kładłam na karb jej niełatwego charakteru. Ale post factum nie mam powodów do narzekań, w takich sytuacjach przypomina mi się, co często powtarzała moja przyjaciółka: „mówisz, że krajobraz jest brzydki, a to brzydota jest w tobie"11. Przyznaję, że niezado-

W. Benjamin O pojęciu historii, w: tegoż Anioł historii: eseje, szkice, fragmenty, przeł. K. Krzemieniowa, Wydawnictwo Poznańskie, Poznań 1996, s. 415.

W. Benjamin Karl Kraus, w: Aniołhistorii.., s. 156.

11 Przyznaję, że Simone Weil nieco inaczej sformułowała tę myśl: „Ja cierpię". Lepiej powiedzieć tak, niż: „Ten krajobraz jest brzydki". S. Weil Wybór pism, przeł. C. Miłosz, Znak, Kraków 1991, S. 117 . 
wolenie, bezradność, bezsilność i złość towarzyszyły mi w pierwszym etapie pracy, ale nie znikały też później. Na szczęście pojawiły się inne pozytywne strony praktyki biograficznej. Dlatego chciałabym w wielkim skrócie opisać moje zmagania z life writing.

Życiopisanie jest pojęciem pojemnym i żadna definicja nie wyczerpuje jego zakresu'12. Najczęściej bazuje on na dokumentach osobistych: listach, wspomnieniach, dziennikach ${ }^{13}$. Wymienia się jego różne cele - do głównych należą: bliskość z przedmiotem badań, oddanie sprawiedliwości wielkim i małym przegranym w naszej historii, ocalenie kobiet/mężczyzn, zwłaszcza przedstawicieli grup dyskryminowanych, od zapomnienia ${ }^{14}$. Oprócz pracy pamięci ważną rolę odgrywa etyczność praktyk przekładająca się na pytania: co należy udostępnić, co trzeba ukryć, jak mówić, żeby sobą niczego nie przesłonić, a jednocześnie powiedzieć, kim była/był, co zrobiła/zrobił.

Namysł nad edycją listów Waligórskiej wydaje się warunkiem sine qua non podjęcia kolejnych prac tego typu. Wybrana przeze mnie metoda life writing nałożyła zobowiązania, które szybko zostały uwewnętrznione jako rodzaj ćwiczeń duchowych. Zwięźle rzecz ujmując, aby sprostać temu zadaniu i móc pracować z widmem Waligórskiej, stałam się częściowo duchem, o czym piszę we wstępie do listów. Ale po wydaniu książki, wróciwszy do mojej własnej cielesnej powłoki, widzę jasno, jaki podjęłam trud. Przez lata nawiedzały mnie sceny z Hańby, kiedy bohater powieści J.M. Coetzeego stał się palaczem zwłok psów. Jego praca, będąca rytuałem quasi-religijnym, polegała na towarzyszeniu im w ostatniej drodze, wykonywane przez niego czynności pogrzebowe miały na celu przywrócenie godności, którą zwierzęta traciły podczas umierania ${ }^{15}$. Długo zastanawiałam się, czy ta posługa miała charakter samoudręki, ekspiacji, pokuty, czy było to poszukiwaniem drogi życiowej.

Długo nie chciałam zrozumieć moich nowych obowiązków ani zgodzić się na nie. Pytania dotyczące wyników moich prac zbywałam milczeniem, gdyż nie chciałam wspominać o rozterkach wewnętrznych. Jednocześnie

12 M. Kadara Coming to terms of life writing - from genre to critical practice, w: Theoretical Discussion of Biography, ed. by H. Renders, B. De Haan, Brill, Leiden-Boston 2014, S 195-205.

13 B. De Hahn The eclipse of biography in life writinig, w: Theoretical Discussion of Biography, s. 177; S. Smith, J. Watson A Guide for Interpreting Life Narratives. Reading Autobiography, University of Minnesota Press, Minneapolis -London 2001.

$14 \mathrm{H}$. Renders Biography in academia and the critical frontier in life writing, w: Theoretical Discussion of Biography, s. 169.

15 J.M. Coetzee Hańba, przeł. M. Kłobukowski, Znak, Kraków 2003. 
rosło we mnie poczucie, że zostałam wezwana, żeby zajmować się zmarłymi. Te ceremonie żałobne nie sprowadzały się wyłącznie do pracy nad edycją, ale zmuszały mnie do odprawiania rytuałów oczyszczających, mających charakter przeprosin oraz próśb o zgodę zmarłych na kontakt, w tym wypadku kierowanych do Waligórskiej. Nawet w trakcie transkrypcji i publikowania dokumentu ogarniało mnie czujne rozkojarzenie, a zarazem byłam w stanie nieprzytomnej uważności, którą można nazwać medytacją czy też modlitwą. Byłam nowicjuszką, nikt mnie nie nauczył, jak należy w sposób właściwy postępować z umarłymi, więc z trudem przecierałam szlaki. Ale widziałam, z jaką łatwością zawłaszcza się dzieła osób nieżyjących, tylko dlatego, że nie mogą wypowiedzieć się w swoim imieniu i zaprotestować przeciwko rabunkowej działalności. Dla wielu badaczy milczenie umarłych jest wyrażeniem zgody na wyprawy łupieskie i grzebanie w cudzych szufladach.

Sądzę, że każdy z badaczy/badaczek powinien odprawić ten rytuał na własną rękę i w sposób dla siebie właściwy, na własną odpowiedzialność, bo wszelka standaryzacja ociera się o groteskę; raczej też powinno to należeć do tajemnicy zawodowej. Jednak nie mogę nikogo zapewnić, że dobrze odprawione dziady gwarantują sukces edytorski i spokój ducha.

\section{Przeszkody}

Patrząc na niebieską okładkę wydanej przeze mnie książki, rozważałam, co wniosły do mojego życia naukowego praca nad edycją listów Bronisławy Waligórskiej i doświadczenie obcowania z nią. Kwestia jest tyleż zasadna, ile banalna. Prawdopodobnie każdy po skończonej pracy zastanawia się nad jej rezultatem. Zazwyczaj takie rozmyślania badaczy/badaczek pozostają jeśli nie ukryte, to prywatne, choć efekty ich działań są upubliczniane i poddawane ocenie przez innych. Nieliczni historycy i biografowie lubią pisać o swoim warsztacie i zastanawiać się nad relacją do przedmiotu badań. Większość jednak automatycznie oddziela się od swojej pracy, koncentrując się na jej wynikach, a nie na własnej kondycji egzystencjalnej. A przecież w trakcie długiej drogi edytorskiej nie wychodzimy z siebie, nie porzucamy swojej duchowo-cielesnej powłoki, która towarzyszy nam cały czas, zazwyczaj bardziej utrudniając nam zmagania, niż w nich pomagając. Ujawnianie się biografa stało się popularne nie tylko we współczesnej literaturze, ale również w metodzie life writing, umożliwiającej dopełnianie się różnych strategii autobiograficznych i tym samym otwierającej się na nowe interpretacje historii i pamięci. 
Przechodząc do kolejnych zadań badawczych, szybko zapominamy o naszych cichych upadkach, wstydliwych niepowodzeniach, męczącym zniechęceniu, ale przecież to one wyznaczają kamienie milowe pracy. Nasze potyczki zaczynają się już na samym początku: zbieranie źródeł, poszukiwania archiwalne, ustalanie faktów, wywiady, kontakty z rodziną są mozolne, niewdzięczne i nie przynoszą łatwych sukcesów. Przełomem jest moment, w którym zaczynamy szukać języka adekwatnego do ujęcia naszego przedmiotu, co w przypadku biografii wydaje się sprawą zasadniczą. Czasami jedyną satysfakcją jest świadomość badacza, że patrzy na czyjeś zamknięte życie jak na ekran i ma możliwość puszczenia tego filmu od początku i/lub od końca. Perspektywa całości wydaje się pomocna w zrozumieniu pewnych zdarzeń, lecz nie pozwala nam wniknąć głęboko w czyjeś pragnienia, które tworzą rozłożysty, częściowo podziemny nurt życia.

Jesteśmy w kłopocie, kiedy chcemy z pewnego dystansu spojrzeć na własne dokonania, a czyniąc to, popadamy w zdumienie, gdyż zamiast nas wyłania się ktoś obcy. Nasze wspomnienia, nawet aktualne wrażenia, są fragmentaryczne i z trudem układają się w koherentną historię. Staje się to tym bardziej problematyczne, gdy próbujemy opisać drugiego człowieka, czy to bliskiego, czy nieznanego, czy oddalonego w czasie; odnoszę wrażenie, że biografowie mimo ciągłych prób forsowania murów, za którymi skrywają się tajemnice ich bohaterów, ciągle pod nimi stoją. Pewnej wiedzy nie gwarantuje też intymny związek z podmiotem. Zebrane już fakty przymierzamy do naszych wyobrażeń i mniemań. Zazwyczaj pod wpływem dotyku materiał rozsypuje się nam w rękach i pozostaje jedynie dobra mina do złej gry. Granica między prywatnościami naszymi, czyli badaczki i przedmiotu/podmiotu badań, nie zostaje nigdy przekroczona.

Łatwo też ulec różnym iluzjom, jak choćby złudzeniu stworzenia czyjegoś kompletnego życiorysu. Hermiona Lee wymienia dziesięć zasad pisania biografii - ma ona m.in. obejmować całe życie, nic nie może zostać pominięte, biograf musi być obiektywny i dobrze znać przedmiot badań. Poza tym, według niej, dzieło powinno być ważne i użyteczne ${ }^{16}$. Takie zadanie każdy powinien stawiać przed sobą, ze świadomością, że cel bywa nieosiągalny.

Często biografowie ukrywają swoje niedostatki, korzystając z technik literackich, które pozwalają im zestrajać z sobą różne elementy, dzięki czemu usuwają fragmentaryczność, nieciągłość, sprzeczne elementy konstrukcji. Znikają wtedy wątpliwości czy też pytania, na które nie ma odpowiedzi,

16 H. Lee Biography. A Very Short Introduction, Oxford University Press, Oxford 2009, s. 56-80. 
dlatego należy cenić tych historyków, którzy łączą uczciwość badawczą z wnikliwą intuicją. Jednym z błędów jest budowanie biografii przez analogie, pomijanie empirii, używanie argumentów perswazyjnych ${ }^{17}$. Łatwo się zgubić, gdyż znaczenie tego, co zaszło, w rzeczywistości nigdy nie jest oczywiste i domniemania mogą przesłonić fakty albo ich brak, co często prowadzi do uproszczeń. Do głównych grzechów należy jednak arbitralna selekcja źródeł. Z drugiej zaś strony odpowiedni dobór materiału, jak twierdzi Leon Edel, jest sztuką i czyni z biografa artystę ${ }^{18}$.

Każdy człowiek tworzy złożoną sieć relacji z innymi w swoim otoczeniu, które nie zawsze, nawet przy szczegółowych badaniach i odpowiednim doborze świadectw, odsłaniają swój prawdziwy wymiar ${ }^{19}$. Tworzenie biografii należy więc przyrównać do budowania pewnej skomplikowanej przestrzeni, będącej rekonstrukcją świata tworzonego przez opisywaną osobę i ją tworzącego. Wynikają z tego skróty, załamania perspektywy, przerysowania, których często nie da się uniknąć. Woolf pisze, że „biograf musi iść przed nami, jak kanarek w kopalni, sprawdzać atmosferę, wykrywać fałsz, nierzeczywistość i obecność przebrzmiałych konwencji. Musi uruchomić i uwrażliwić całe swoje poczucie prawdy [...] biograf musi być przygotowany na to, by godzić sprzeczne wersje tej samej twarzy. Biografia poszerza swój zakres, rozwieszając tu i tam lustra"20.

Ale to grozi popadnięciem we własny świat wyobraźni, gdzie młyny fikcji pracują bez przerwy.

\section{Niebezpieczeństwa}

Samoświadoma biografka stara się unikać pułapek imaginatywnego zaangażowania, identyfikacji, samoprojekcji, a empatię osiąga bez przeniesienia, zachowuje dystans do końca i nie porzuca po drodze naukowego bagażu²1.

Życiopisanie ma ciemną stronę i trzeba o tym pamiętać. Należy do niej sentymentalizm będący efektem ubocznym związku z naszym bohaterem lub

17 J. Walter The solace of doubt? Biographical methodology after the short twentieth century, w: Theoretical Discussion of Biography, s. 44.

18 Tamże.

19 H. Renders Biography in academia, s. 170.

20 V. Woolf Sztuka biografii, s. 321.

21 J. Walter The solace of doubt?, s. 47. 
naszą bohaterką. Obłuda daje nam komfort bycia dobrymi, gdyż dzięki niej postrzegamy się jako ci, którzy ratują ofiary przemocy historii od zapomnienia. Za hipokryzją podąża ukryte pragnienie władzy zdobywanej podczas biograficznej pracy. Wielkim niebezpieczeństwem dla life writing jest niekontrolowany transfer, którego symptomy odnajdywałam we własnej praktyce. Należy więc pozbyć się złudzeń, że zmarli nas kochają. Bo jak mówiła Monella: „Nie całuj umarłych: oni duszą żywych"22. Musimy się chronić, gdyż nasza naiwność, wrażliwość, empatia mogą nas wywieść poza granice rozumu, w regiony, gdzie można się zgubić i nie odnaleźć drogi powrotnej.

Bliskość jest zabójcza, obraca się przeciwko nam, możemy stać się osobą nawiedzaną przez swoje fantomy, jak bohater Solaris Stanisława Lema. Kris Kelvin wywołuje swoją zmarłą żonę Harey. Na dalekiej planecie, w odpowiedzi na wezwanie oceanu, jego podświadomość dokonuje niekontrolowanych projekcji. Pozbywając się dystansu do naszych nieżyjących bohaterów/bohaterek, wytwarzamy fantazmaty, które, tak w jak w przypadku psychologa astronauty, utkane są z naszych marzeń, lęków, wyobrażeń, ograniczeń. Nie potrafię też wskazać, jaki sposób jest najlepszy, by nie zatracić siebie i nie utracić widma. Najczęściej badacze wycofują się, oddając głos podmiotowi. Zamiast dokonywać aktów anihilacji własnej podmiotowości, można próbować negocjować własną obecność w życiu duchów. Przypomina to półjawne działania osoby ukrywającej się za kurtyną, a jednak nadal stojącej na scenie. Polega to na dyskretnym tworzeniu narracji, przypominającym splatanie mało widocznych węzłów i tworzenie spojeń,czy też łączenie porozrywanych wątków. Autorka biografii może się wtedy odsłaniać, chociaż jej obecność w cudzym ciele jest zawsze niestosowna, dziwna, niezręczna i paradoksalna. Gest ten ma jednak siłę ożywienia całości, pod warunkiem że sytuuje się na krawędzi tekstu.

Istnieje też jeszcze jeden sposób - to pociągająca i ryzykowna biograficzna przygoda poza naszym światem, gdzie otwiera się inna widzialność i możliwa jest odmienna percepcja. Poprzez wprowadzenie fikcji dokonujemy „unerwienia tego, co nie istnieje"23. Ożywiamy naszą bohaterkę, dajemy jej dodatkowe życie, które też może być naszym, chociażby przez sam akt kreacji i pisania. Pozbycie się ciężkiego ekwipunku badaczki, wyjście ze sfery prawdy, poprzez mosty prawdopodobieństwa, do świata niemożliwego jest

22

M. Schwob Księga Monelli, przeł. B. Ostrowska, w: Żywoty urojone i inne prozy, PIW, Warszawa 2016, s. 178 . 
wyznaczeniem szerszej perspektywy dla tych, których już nie ma. A w sferze imaginacji my również w jakimś stopniu nie istniejemy, więc jest to wspólna płaszczyzna, przestrzeń dla piszącego „ja” i nowego wcielenia osoby opisywanej. Fikcja zaświadcza o naszym nieistnieniu, niezbywalnej części naszej kondycji. A język fikcji, który już tylko z daleka krąży po obrzeżach dzieła naukowego, wyzwolony ze wszystkich ograniczeń, dociera do źródłowości, mającej charakter epifanii. Doświadczyłam tego, pisząc listy Waligórskiej o jej podróży do Łodzi i tam przeprowadzonej przez działaczy Proletariatu agitacji oraz akcji terrorystycznej. Kartki z podróży pisane na podobieństwo więziennej korespondencji Bronisławy Waligórskiej z jej siostrą Jadwigą nie wzbudziły żadnych podejrzeń, że zostały wymyślone. Znając niemal na pamięć frazy z jej korespondencji, wyczuwając styl Waligórskiej, niemal z łatwością odtwarzałam sposób wyrażania przez nią myśli i wrażeń. Wprowadziłam również postać fikcyjną, która miała cechy podobne do moich, dzięki czemu obie - ja i Waligórska, spotkałyśmy się w świecie wyobrażonym. Tego rodzaju technik użyli Julian Barnes (Papuga Flauberta) czy A.S. Byatt (Opętanie), wprowadzając do powieści (auto)biograficznych swoje alter ego, prowadzące biograficzne śledztwo i rozwiązujące liczne zagadki. Miało to walor z pewnością nie tylko literacki, ale i terapeutyczny. Mój eksperyment był eksperymentem duchowym i próbą opisania doświadczenia widmowej obecności Waligórskiej.

Ostatecznie zwyciężył rozsądek. Przygotowując krytyczne wydanie listów Bronisławy Waligórskiej, odwołałam się do tego sposobu, który niemal całkowicie oddaje głos autorce listów, było to podyktowane zasadami warsztatu historycznego, gdyż ostatecznie głównym celem było oddanie sprawiedliwości, przywrócenie zapomnianej postaci z naszej przeszłości.

\section{Bronisława i ja}

Bronisława Waligórska, córka Aleksandra, powstańca 1831 i 1863 roku, urodziła się w Christianii. W wieku dwunastu lat trafiła do sierocińca św. Kazimierza w Paryżu. Po niespełna roku została oddana na wychowanie do klasztoru św. Jana w Krakowie, gdzie spędziła młodość. Wiemy, że po 1865 roku wyjechała do Rejowca, a potem do Warszawy, gdzie pracowała jako prywatna nauczycielka. W tym czasie zbliżyła się do rewolucyjnego ruchu robotniczego. Nie wiemy, kiedy dokładnie wstąpiła do Proletariatu. Jako osoba wykształcona była odpowiedzialna za zebrania kółek robotniczych, w ich ramach przygotowywała wykłady i pogadanki dla robotników. W 1885 roku weszła 
do władz partii. Wspólnie z Julią Razumiejczyk i Władysławem Wisłockim przygotowywała plan zamachu na zdrajcę i donosiciela - Pińskiego, agitowała robotników do podjęcia akcji terrorystycznych oraz dokonania zemsty na zdrajcach ${ }^{24}$. Determinacja zamachowców graniczyła z desperacją i zaślepieniem, gdyż jedyną bronią, jaką posiadali, były sztylety i pałki plecione ze skóry, z metalowymi gałkami w środku, i jeden pistolet. W opinii jej współczesnych i historyków ruchu robotniczego Waligórska była bardzo radykalna, co stało w sprzeczności z tym, co sama o sobie pisała w listach do siostry ${ }^{25}$. Aresztowana, spędziła kilka miesięcy w warszawskiej cytadeli. Jej listy do siostry Jadwigi są wyrazem bezsilności, bezradności, głębokiej rozpaczy, rozstroju nerwowego. Wiemy, że w przeciwieństwie do pozostałych aresztowanych osób nikogo nie wydała i do końca broniła swoich ideałów. Otruła się siarką i zmarła na początku stycznia 1887 roku w strasznych cierpieniach.

Podstawą publikacji były autografy znajdujące się w Bibliotece Polskiej w Paryżu ${ }^{26}$. Listy, w większości niedatowane, nie były ułożone chronologicznie. Nie chcę jednak pisać o problemach edytorskich, ale muszę się przyznać, że od początku nie mogłam znaleźć klucza do czytania tej korespondencji. Uległam sugestiom innych badaczy i znalazłam się na manowcach, m.in. uwierzyłam innym, bardziej doświadczonym edytorom, że nieocenioną pomocą w ustaleniu kolejności listów są Lettres de prison, rękopis Władysława Mickiewicza z $1907 \mathrm{roku}^{27}$. Powstała więc pierwsza wersja edycji, która budziła moją nieufność. Czytając korespondencję, zorientowałam się, że Mickiewicz posłużył się nią instrumentalnie, jako przykładem na funkcjonowanie carskiego terroru, i nie był zainteresowany przypadkiem Waligórskiej. Odkrycie to pozwoliło mi odłożyć na bok, to co zostało zrobione i skierowało mnie na inne tory, które okazały się równie wyboiste i trudne, i do końca nie mogę też powiedzieć, że właściwe.

Miałam nawet w planie opisać to błędne rozeznanie, dołączyć poprzednią edycję do obecnej, zestawić wstępnie ustaloną, ale budzącą zastrzeżenia

24 Akta śledztwa w sprawie Piotra Pińskiego znajdują się w zespole „Prokurator Warszawskiej Izby Sądowej 1876/1918" w warszawskim AGAD-zie. Częściowo zostały opublikowane w: Kółka socjalistyczne, gminy i Wielki Proletariat. Procesy polityczne 1878-1888: Źródła, zebrał, oprac. i wstępem opatrzył L. Baumgarten, Warszawa 1966. Zob. L. Baumgarten Dzieje Wielkiego Proletariatu, Książka i Wiedza, Warszawa 1966, s.728-729, 741-743. 
chronologię, nietrafny układ listów z obecnym, gdyż wydawało mi się, że będzie to pouczające dla wszystkich zajmujących się wydawaniem rękopisów. W naszej pracy przecież nie tylko ulegamy sugestiom, ale też dajemy się uwieść przekonującym tezom, podążamy za autorytetami, by w końcu odkryć, że są to drogi prowadzące donikąd. To doświadczenie jest wspólne wielu badaczom, o swoim zauroczeniu i uwiedzeniu przez znanego amerykańskiego badacza, znawcę dorobku Helene Deutsch pisze Jolanta Żyndul ${ }^{28}$. Niekiedy sami popełniamy błędy i bywa tak, że dopiero po jakimś czasie widzimy, że za bardzo ufaliśmy własnej intuicji. O tym, jak trudno pogodzić się i wrócić po latach do punktu wyjścia naszych badań, żeby zweryfikować nasze fałszywe tezy, rozmawiałam z Marią Janion, która opowiadała o swojej pracy nad życiem i twórczością Zygmunta Krasińskiego ${ }^{29}$.

Praca nad edycją listów wydawała się typowa dla tego rodzaju pisania biograficznego, kiedy źródeł jest niewiele albo są skąpe, albo prawie ich nie ma. O Waligórskiej mało wiadomo. Poza listami, dokumentami dotyczacymi ojca, aktami śledztwa znajdującymi się w warszawskim Archiwum Głównym Akt Dawnych - nie ma nic więcej. Niedostatek źródeł zmusił mnie do zastanowienia się nad innymi rozwiązaniami: zaczęłam szukać kontekstów i zajęłam się opisaniem środowiska Proletariatu, co pozwoliło umieścić postać Waligórskiej w danym momencie historycznym i właściwym miejscu. Zastanawiałam się, do jakiego stopnia może być ona przeze mnie potraktowana jako wyjątek versus reprezentacja grupy, czego świadectwem była jej działalność rewolucyjna ${ }^{30}$. Kalendarium obejmujące czasy jej działalności partyjnej, nieudaną akcję, czyli zamach na Pińskiego, więzienie i samobójczą śmierć miało być dowodem na reprezentatywność działaczki Proletariatu. Jednakże zaprzeczały temu listy, będące świadectwem jej wyjątkowości, dlatego też postanowiłam skoncentrować się na jej życiu więziennym.

Największym wyzwaniem były rozsypane listy, które trzeba było ułożyć, a potem znaleźć klucz do wielu niewiadomych. Korespondencja jest o tyle nietypowa, że miała jednego dodatkowego czytelnika, cenzora, który skrupulatnie oglądał każdą najmniejszą karteczkę. Kolejne pytania o to, jak

28 J.Żyndul Podwójne życie Heleny. Polskie wątki biografii Heleny Deutsch jako część historii psychoanalizy, w: Przywracanie pamięci. Polscy psychiatrzy w XX wieku orientacji psychoanalitycznej, red. P. Dybel, Universitas, Kraków, s. 523-547. Rozmowa odbyła się 2 września 2018 roku w domu profesor Marii Janion. 
listy znalazły się w Paryżu, kto je czytał poza Władysławem Mickiewiczem, pozostały zagadką.

Podczas pracy musiałam konfrontować się z różnymi nierozstrzygalnikami, jednak sprawą zasadniczą było zagadnienie, czy obraz Waligórskiej, jaki zaczął się z tego wyłaniać, jest moim odbiciem, wizerunkiem ograniczonym przez moją osobę, i do jakiego stopnia mogę się ujawnić. Odnosiłam wrażenie, że zaczynam przypominać doktora Frankensteina, który tworzy kogoś na własne podobieństwo. Obawiając się więc, żeby efekty nie zaskoczyły mnie i czytelników, starałam się trzymać dyscyplinę pozwalającą na kontrolowanie moich zabiegów upiększających. Balansowałam między sprzecznościami, między wolnością, przypadkowością a koniecznością, między faktami a domysłami, wiedzą a intuicją. Po ukończeniu pracy zostałam z poczuciem, że prawda pozostaje niewyrażalna, a doświadczenie tej pracy - w dużym stopniu niekomunikowalne.

\section{Spacja przed dwukropkiem}

Na koniec chciałabym wspomnieć o tym, czego nie ma w książce Listy z cytadeli.1886, a więc opisać ślad śladu, za który uważam „spację przed dwukropkiem". Waligórska w listach stawiała bowiem spację przed dwukropkiem. Przyczyny tego są niejasne, być może była to cecha osobnicza, a może tradycja francuska. W edycji ten zapis został zachowany zgodnie z zasadą integralności tekstu, ja zaś we wstępie, naśladując moją bohaterkę, zrobiłam to samo. W trakcie korekty i składu moje spacje znikły, uznano je za niezasadne i dziwaczne, pozostały jednak w mojej pamięci nie tyle jako akt naśladowczy, przeniesiony z jednego świata do drugiego, ile rodzaj szpilek fastrygujących oba wymiary. Patrząc z dystansu na moją pracę, nazwałabym to zawarciem przymierza z osobą, o której pisałam.

Trud edycji kazał mi też postawić osobiste pytanie: czym było moje pisanie o Waligórskiej? Trawestując zdanie Edmonda Jabèse’a, mogę wyznać, że "zaczęło się od skaleczenia"

W średniowieczu widziano związek między cielesnością a pisaniem z tego względu, że używano pergaminu do robienia ksiąg. Sama produkcja materiału przypominała potworne, pośmiertne tortury: skórę z zabitego zwierzęcia

31 J. Derrida cytuje Edmonda Jabèse'a, który w Księdze pytań pisze, że każda „wypowiedź poetycka poczyna się od skaleczenia". J. Derrida Pismo i różnica, przeł. K. Kłosiński, KR, Warszawa 2004, S. 111. 
oczyszczano z sierści, a następnie nacinano na niej linie za pomocą noża. Wydaje się, że uwewnętrzniony obraz męki nieżyjącego już ciała jest w bliskiej relacji z torturami tworzenia w sferze duchowej i psychicznej ${ }^{32}$. Nacinamy pustą przestrzeń, stawiając swój ślad na papierze/ekranie, który w rzeczywistości jest odbiciem naszego wewnętrznego napięcia. Nic dziwnego, że kiedy zaczynamy pisać, pojawia się ból. Bronimy się przed tym na różne sposoby, stawiamy opór, szukamy ucieczki przed udręką. Pierwsze wersje naszych tekstów powinny być pisane czerwonym atramentem albo czerwoną czcionką, bo chyba nieprzypadkowo porównywano rany męczenników z czerwonym pismem ${ }^{33}$.

Czy jednak rzeczywiście wstępujemy w pustkę? Stoimy tylko na progu, który symbolizuje biała kartka papieru/ekran, i trzeba się przyznać, że wchodzimy naszym ciałem w cudzy organizm. Dokonujemy więc wtargnięcia i przedzieramy się przez teksty innych, odmienne od naszych myśli i obce nam tajemnice. Często nawet nie zauważamy, kiedy nasze pisanie staje się zamazywaniem tego, co pod spodem - nakładamy nasze teksty na inny grunt. Stawiałam sobie wielokrotnie pytanie, jaki jest owoc moich działań, czy ze słów wyrasta coś nowego, czy zostawiam spaloną ziemię. Podczas opracowywania edycji listów, przez te kilka lat odnosiłam wrażenie, że stawiam ślady w miejscu pokrytym grubą warstwą kurzu. Moje pisanie w czarnej wodzie było rozgrzebywaniem popiołów.

Często nawiedzało mnie pytanie, czy stan, w którym znajdujemy się podczas pisania, jest życiem czy śmiercią. Najczęściej przypominało to lżejszą formę śmierci, będącą zawieszeniem życia, w której rządzi bezosobowa siła. Agamben nazywa to częścią niezindywidualizowaną, której nie można zredukować do ego czy jednostkowej świadomości ${ }^{34}$. To doświadczenie ujawnia się w sferze duchowej. Ten ładunek bezimiennej rzeczywistości

Ernst Robert Curtius podaje taki przepis: „najpierw kopista oczyszcza pergamin z tłuszczu i innych nieczystości za pomocą noża. Następnie usuwa sierść i włókna pumeksem. Gdyby tego nie uczynił, litery na nim zapisane nie byłyby trwałe i na nic by się nie zdały. Później kreśli on linie na pergaminie, ażeby pismo było równe". E.R. Curtius Literatura europejska i łacińskie średniowiecze, przeł. A. Borowski, Universitas, Kraków 1997, s. 325.

33 Tamże, s.322.

34 Według Freuda i później Agambena „istota ludzka nie daje się zredukować do Ego i jednostkowej świadomości, ale od narodzin do śmierci występuje z bytem bez-i przedosobowym. Innymi słowy człowiek nie jest istotą dwoistą, lecz dwubiegunową, wypadkową złożoną z relacji dialektycznej między częścią (jeszcze) niezindywidualizowaną w toku życiowych doświadczeń a częścią doświadczaną jako los i życie". G. Agamben Profanacje, s. 19-20. 
należy pielęgnować i szanować. Bezosobowe „ja” jest światłem między literami, wyrazami, zdaniami, spacją przed dwukropkiem; umożliwia ono pisanie, to rodzaj retardacji, medytacji, zawieszenia, oczekiwania. I sprzyja pojawieniu się widma. Kiedy ogarnia nas ta pozajednostkowa siła, kiedy uwalniamy nasze niewyodrębnione „ja”, otwiera się inna wewnętrzna przestrzeń, możemy nazwać ją „kryptą" ${ }^{35}$, gdzie nawiedza nas widmo osoby, o której piszemy. Intymne obcowanie z istotą obcą pozostaje blisko sfery niewiedzy, ale "nie jest to obszar stłumienia, przemieszczenia, spychania doświadczeń świadomości w głąb nieświadomości”36. Jest to „osobliwie radosne doświadczenie ezoteryczne" ${ }^{37}$, w którym ego tylko z daleka asystuje temu doświadczeniu.

Podczas pisania wchodzimy więc w obce ciało, by następnie otworzyć w sobie ciemną więzienną celę i spotkać widmo. Przygotowana edycja listów okazała się dla mnie pracą żałoby, dokonywała się ona przez mówienie/milczenie: stawianie tajemnych znaków - spacji.W miejscu, w którym dochodzi do spotkania, często nawet po jego zakończeniu trwa owa niesymetryczna, chroma rozmowa, gdyż nie można odpowiedzieć na wezwanie zmarłego. Jeśli jesteśmy wierni zmarłym, nawet po rozstaniu krypta/cela zostaje w nas. I nie ma znaczenia, że jest już wtedy pusta.

Pojęcie krypty pożyczam od Derridy, nadając mu jednak mniej skomplikowane znaczenie, niż to zrobił francuski filozof. Zob. J. Derrida Fora. "Kanciaste” słowa Nicolasa Abrahama i Marii Torok, przeł. B. Brzezicka, „Teksty Drugie” 2016 nr 2, s. 122-168, a także tegoż The work of mourning.

37 Tamże, s. 21. 


\section{Abstract}

\section{Monika Rudaś-Grodzka}

THE INSTITUTE OF LITERARY RESEARCH OF THE POLISH ACADEMY OF SCIENCES (WARSAW)

A Farewell to Bronisława Waligórska: Biographical Practices

Bronisława Waligórska was a teacher born in the 1840s and arrested for terrorist activities in 1886. Her letters to her sister, written from the Warsaw Citadel until Waligórska's suicide in January 1887, were edited by Monika Rudaś-Grodzka and published in 2018. In this article Rudaś-Grodzka discusses the benefits and drawbacks of the method of life writing she applied in her editorial work - a method based on personal documents such as memoirs, letters and journals.

\section{Keywords}

biography, life writing, correspondence 